UDC 669.295

\title{
THE REFINING OF TITANIUM BY METHOD OF ZONE RECRYSTALLIZATION IN AN ELECTRIC FIELD
}

\author{
O.E. Kozhevnikov, M.M. Pylypenko, V.M. Pelykh, V.D. Virych, M.F. Kozhevnikova \\ National Science Center “Kharkov Institute of Physics and Technology”, Kharkiv, Ukraine \\ E-mail: kozhevnikov@kipt.kharkov.ua
}

The physical substantiation and an experimental study results of the application of zone recrystallization method in an electric field for the refining of titanium are presented. The elemental composition, microstructure and microhardness of the samples have been investigated. It is shown that refining process made it possible to significantly reduce the content of both metallic and gas-forming impurities. The oxygen concentration was reduced by 2.2 (from 0.033 to 0.015 wt.\%), carbon - by 3.3 (from 0.01 to 0.003 wt.\%), nitrogen - by 22 times (from 0.009 to 0.0004 wt.\%). The purity of the obtained samples was characterized by a value of $99.95 \mathrm{wt} \%$ by titanium content. The total amount of impurities had been reduced by a factor of 2.4 (from 0.12 to $0.05 \mathrm{wt} . \%$ ).

\section{INTRODUCTION}

The introduction and use of high-efficiency fuel cycles at operating nuclear power plants with watercooled power reactors (WWER) has contributed to an increase in the service life of vessel equipment and fuel elements, in an increase in fuel burnup and the steam content of the coolant. The resource and safety of nuclear reactors depend on the characteristics of the materials used. Zirconium, hafnium, titanium, and also alloys based on them are widely used as structural and absorbing materials in thermal-neutron reactors [1].

The properties of titanium depend significantly on the content of impurities in the metal. Although the impurities increase the strength, at the same time, they sharply decrease the plasticity, and the most severe negative effect is caused by interstitial impurities. When the hydrogen concentration is only $0.003 \mathrm{wt} . \%$, nitrogen is $0.02 \mathrm{wt} . \%$ or oxygen is $0.7 \mathrm{wt} . \%$, titanium completely loses its ability to plastic deformation and breaks down brittle.

Among the impurities harmful to the ductility of titanium carbon, iron, and silicon should also be included.

The resulting effect of impurities is also expressed in the fact that technical titanium undergoes allotropic transformation not at a temperature of $882{ }^{\circ} \mathrm{C}$, but in a temperature range of $865 \ldots 920{ }^{\circ} \mathrm{C}$ [2].

On an industrial scale, to obtain high-purity titanium an electrolytic refining (ER) or iodide process (IP) is used. The ER process makes it possible to increase the purity of titanium materials relatively to gas impurities (oxygen and nitrogen), as well as carbon, silicon, iron, and other impurities.

The process of refining of titanium sponge using a $\mathrm{CaCl}_{2}-\mathrm{TiCl}_{2}$ melt was described in [3]. At optimally selected electrolysis mode (melt temperature $-900{ }^{\circ} \mathrm{C}$, current density $\left.-0.5 \mathrm{~A} / \mathrm{cm}^{2}\right)$ titanium with a purity about $99.95 \%$ was obtained.

The iodide refining method is based on the reversibility of the formation reaction and on thermal dissociation of gaseous tetraiodide of the base metal. The use of IP makes it possible to purify titanium from nitrogen, hydrogen, oxygen, carbon and some other impurities, using also waste and production turnovers as raw materials [4].

Earlier in the NSC KIPT the work on the refining of metal by the method of electron beam melting in a vacuum was carried out. Titanium sponge TS-90 and titanium after iodide refining were used as raw materials. The high efficiency of the refining process from metal and gas impurities was shown. A metal with a purity of $99.95 \%$ was obtained [5].

The crystallization process from melts is one of the main methods for refining of metals and semiconductor materials. During zone melting (ZM), the refining occurs as a result of zone redistribution of impurities between the melt and the solid phase. Usually, ZM is used at the final stages to remove low concentrations of impurities.

Electrotransport is used for deep refining of metals in solid and liquid states. The method is based on the ability of impurity ions to displace directionally over the sample under the action of an applied constant electric field.

Previously an investigation of titanium refining by crucibleless vacuum zone melting in an electric field (ZMEF) were hardly carried out. The purpose of this work is to physical substantiation and experimentally study of the behavior of metallic and gas-forming impurities during the refining process of titanium by the ZMEF method.

\section{PHYSICAL SUBSTANTIATION OF TITANIUM REFINING BY METHOD OF ZMEF}

The refining of titanium by the ZMEF method is carried out with the simultaneous passage of several physical cleaning processes:

- when melting is carried out in vacuum conditions, the vaporization process is occurs. It refers gas-forming impurities and also those metallic impurities that are characterized by a high value of the saturated vapor pressure at the melting temperature of titanium;

- due to the zonal redistribution of impurities between the melt and the solid phase. At the same time they are displaced to the end part of the ingot together with the movement of the liquid zone during the $\mathrm{ZM}$; 
- due to the migration of impurity ions under the action of an applied direct electric field to the end parts of the sample (to anode or cathode).

The principle of zone refining is based on the different solubility of impurity in the liquid and solid phases of the base material. An important characteristic in describing of the process is the distribution coefficient $k$, which represents the ratio of the impurity concentration in the solid phase $C_{S}$ to the concentration in the melt $C_{L}[6]$ :

$$
k=C_{S} / C_{L}
$$

There are the differences between concepts of equilibrium distribution coefficient $k_{0}$ and effective distribution coefficient $k_{e}$. The equilibrium distribution coefficient $k_{0}$ is usually determined from the "baseimpurity" phase diagram or from the ratio of the maximum solubility of an impurity to its concentration at the point of invariant transformation. When $k_{0}$ must be calculated in the case of low impurity concentrations, it seems most convenient to use theoretical methods based on the thermodynamic constants of equation for ideal solutions. According to this concept, it can be used the Schroeder-Le Chatelier equation:

$$
\begin{aligned}
& \ln \frac{C_{L}}{C_{S}}=-\frac{\Delta H}{R}\left(\frac{1}{T_{b}}-\frac{1}{T_{G}}\right)=\theta \\
& \text { Then } \frac{C_{L}}{C_{S}}=e^{\theta}, \text { and } k_{o}=1 / e^{\theta} .
\end{aligned}
$$

Here $\Delta H$ is the molar heat of fusion for impurity, $\mathrm{J} / \mathrm{mol}$; $R$ is the universal gas constant $(R=8.314 \mathrm{~J} /(\mathrm{mol} \cdot \mathrm{K}))$; $T_{b}$ is the melting temperature of the titanium $\left(T_{b}=1943 \mathrm{~K}\right) ; T_{G}$ is the hypothetical value of the melting temperature of "base-impurity" alloy, which is selected from the kind of phase diagram [7].

When carrying out the ZM process, it is necessary that the rate of crystallization be greater than the diffusion rate of the impurity in the solid phase of the base material, but also does not exceed some optimal value. In this case, the moving crystallization front repels the dissolved impurity faster than it can evenly distribute in the melt, and an impurity-enriched region called the diffusion layer appears before the crystallization front. The width of the diffusion layer depends on the diffusion ability of the impurity, the viscosity of the melt, the nature of the fluid motion, the rate of crystallization.

Therefore, the main characteristic of process of the zone impurity separation is effective distribution coefficient $k_{e}$, which can be calculated by the BurtonPrim-Slichter formula [6]:

$$
k_{e}=\frac{1}{1+\left(\frac{1}{k_{0}}-1\right) \cdot e^{-\frac{v \delta}{d}},}
$$

where $v$ is the speed of zone movement; $d$ is the diffusion coefficient of the impurity in the melt; $\delta$ is width of the diffusion layer.
For most metals the value of the diffusion coefficient $d$ is $5 \cdot 10^{-5} \mathrm{~cm}^{2} / \mathrm{s}$ approximately. The value of the diffusion layer width $\delta$ equals approximately $0.01 \mathrm{~cm}$ in the case of conservative melt mixing in the liquid zone. Therefore, the $\delta / d$ ratio is $200 \mathrm{~s} / \mathrm{cm}$.

An analysis of the results of titanium refining by crucible-free ZM method in vacuum was carried out in [8]. It was noted that a good degree of purification from metal and gas-forming impurities was achieved at high speeds of zone movement (16 and $8 \mathrm{~mm} / \mathrm{min}$ ) due to their evaporation. ZM made it possible to significantly reduce the concentrations of $\mathrm{Al}, \mathrm{Ca}, \mathrm{Co}, \mathrm{Cr}, \mathrm{Cu}, \mathrm{Fe}, \mathrm{K}$, $\mathrm{Mn}, \mathrm{Na}, \mathrm{Ni}, \mathrm{P}, \mathrm{S}, \mathrm{Si}$. These impurities are characterized at $T=1933 \mathrm{~K}$ by value of the saturated vapor pressure $P^{0}>50 \mathrm{~Pa}$. The value of saturated vapor pressure for titanium at the melting point is $0.6 \mathrm{~Pa}$ [9].

The applying of $\mathrm{ZM}$ with a speed of 4 and $2 \mathrm{~mm} / \mathrm{min}$ allowed cleaning from metal impurities also. As a result, the concentration of aluminum was reduced by 1.6 ; iron -1.3 ; calcium -1.4 ; cobalt -4 ; manganese - 7; nickel - 1.74; copper - 44; phosphorus - 1.4 times. The refining was carried out from interstitial impurities also effectively. The oxygen concentration was reduced from 0.033 to $0.025 \mathrm{wt} \%$, carbon from 0.01 to 0.0048 wt. $\%$, nitrogen from 0.009 to 0.0035 wt. $\%$ [8].

In [10], experimental data were presented that testified to the occurrence of relaxation processes in $\alpha$-titanium single crystals, which were grown by crucibleless ZM method. The study was carried out after the passage of the front of the $\beta-\alpha$ transformation. It was found that the nature of the structural manifestations of relaxation processes and their efficiency depend on the purity of the material and the crystallographic orientation of the single crystals.

The theoretical theses of the substance cleaning in solid and liquid phases under the influence of an applied direct electric field were described sufficiently in $[11,12]$. The passing of a direct electric current through a metal sample leads to a displacement of impurity ions in a certain direction (to anode or cathode). The electric current passing through the phase boundary changes the value of the effective distribution coefficient $k_{e}$ due to the addition of the electrotransport component to the diffusion flux. In general terms, the resulting force $F$ acting on the impurity ion in the base metal can be expressed as:

$$
F=(Z-|e| n L \sigma) E=Z^{*} E,
$$

where $Z$ is the ion charge; $e$ is the electron charge; $n$ is the concentration of conduction electrons; $L$ is the mean of electron free pass; $\sigma$ is the cross-section of scattering of electrons on the impurity ion; $E$ is the electric field strength; $Z^{*}$ is the effective ion charge $\left(Z^{*}=Z-|e| n L \sigma\right)$.

The value of $Z^{*}$ can be determined from the expression:

$$
Z^{*}=\frac{U k T}{D e},
$$

where $U$ is the ion mobility; $D$ the diffusion coefficient of the impurity ion in the case of ZMEF process; $T$ is the temperature of base material; $k$ is the Boltzmann constant [13]. 
Depending on the sign of $Z^{*}$, the resulting force $F$ can be directed to the cathode $\left(Z^{*}>0\right)$, to the anode $\left(Z^{*}<0\right)$, or equal to zero $\left(Z^{*}=0\right)$.

The value of the impurity ion mobility $U$ depends on the properties of the system and the temperature. In the case of highly dilute solutions, the rate of movement of the solvent ion can be set equal to zero, and the expression for the impurity ion mobility can be represented as:

$$
U=v^{\prime} / E .
$$

In the case of carrying out the ZMEF process equation (3) for the effective distribution coefficient of the impurity takes the form:

$$
k_{e}^{\prime}=\frac{1+\frac{v^{\prime}}{v}}{1+\left[\frac{1}{k_{0}}\left(1+\frac{v^{\prime}}{v}\right)-1\right] \cdot e^{-\frac{v \delta}{D}\left(1+\frac{v^{\prime}}{v}\right)}},
$$

where $\mathbf{v}^{\prime}$ is the speed of impurity ion displacement.

Under the influence of an electric field, the value of $k_{e}^{\prime}$ can be changed.

This makes it possible to obtain the following results:

1) the efficiency of refining can be increased;

2) the value of $k_{e}^{\prime}$ can be made less than unity even for those cases when $k_{0}>1$, which allows the refining during recrystallization.

It should be noted that the making of calculations does not include a number of other effects, which may occur at the interface of "liquid-solid" and may affect the magnitude of $k_{e}^{\prime}$. Particularly a Peltier effect not considered (the release or absorption of additional heat at the phase boundary). In this case, an additional component of the impurity flow arises in the liquid zone due to diffusion in the thermal gradient field, which can affect on the cleaning efficiency.

In article [14], the displacement of interstitial impurities under the action of an applied constant electric field in the high-temperature $\beta$-phase of titanium at temperatures from 1610 to $1860 \mathrm{~K}$ was considered. Based on the results of the analysis of the elemental composition of the samples, the values of mobility $U$, ion movement speed $v^{\prime}$ and diffusion coefficient $D$ were calculated (for carbon, nitrogen and oxygen ions). It was noted that during the electrotransport in the $\beta$-phase of titanium, a displacement of carbon ions to the cathode, and oxygen and nitrogen ions to the anode were observed. The results of elemental analysis made it possible to calculate the value of the positive value of the effective charge $Z^{*}\left(Z^{*}>0\right)$ for carbon ions and negative values of $Z^{*}\left(Z^{*}<0\right)$ for oxygen and nitrogen ions in the $\beta$-phase of titanium.

\section{EXPERIMENTAL STUDY \\ OF TITANIUM REFINING}

\subsection{RESEARCH METHODS AND MATERIALS}

In the presented work the obtaining of refined titanium samples was carried out using the crucibleless ZM method with electron-beam heating in a vacuum of $1 \cdot 10^{-4} \mathrm{~Pa}$. The advantages of this type of melting include the ability to refine samples and to grow single crystals of refractory metals and alloys, the absence of a crucible, the creation of a narrow heating region by focusing the electron beam, and a high specific power concentration. A detailed description of the ZM device for refining of refractory metals is given in [15].

As the starting material was used industrial titanium obtained by refining iodide method with integral purity of 99.88 wt.\%.

The results of the impurity content were obtained by laser mass spectrometry. In the analysis, an EMAL-2 energy-mass analyzer was used. The limiting sensitivity of the analysis method for metal impurities was $10^{-6}$ at.\%. The device was calibrated with certified LECO samples.

The visual inspection of thin sections and photographing of the grain structure were carried out using an MMR-4 microscope. The microhardness was measured on a PMT-3 microhardness tester at a load of $0.05 \mathrm{~kg}$. The value of the microhardness numbers was recorded by ten measurements. The measurement error did not exceed $5 \%$.

\subsection{RESULTS AND DISCUSSION}

An analysis of the "titanium-impurity" phase diagrams in the case of the Ti-O and Ti-N systems (Fig. 1,a,b) shows that even small additions of these impurities sharply increase the melting temperature of the alloys. For them, the value $k_{0}>1$. Nitrogen and oxygen belong to the group of elements that dissolve significantly in $\alpha$-titanium and sharply increase the temperature of $\alpha-\beta$ polymorphic transformation.

Carbon with small concentration lowers the melting point of titanium from 1663 to $1653{ }^{\circ} \mathrm{C}$, which is the temperature of eutectic crystallization $\mathrm{L} \leftrightarrow \beta$-Ti + $\mathrm{TiC}(\delta)$. The eutectic contains 1.5 at. $\%$ of carbon. Therefore, the value $k_{0}<1$ in range of small concentration. Carbon increases the temperature of $\alpha$ - $\beta$-transformation of titanium from 882 to $920{ }^{\circ} \mathrm{C}$, which is the temperature of the peritectoid reaction of $\alpha$-Ti formation (see Fig. 1,c) [16].

The calculations of the distribution coefficients $k_{0}$ for impurities in titanium were carried out taking into account the thermodynamic constants of the equation of ideal solutions according to formula (2). Expression (3) was used to calculate the value of the effective coefficient $k_{e}$. The following parameters were taken into account in the calculations: $T_{G}$ is the estimated value of the melting temperature of the base-impurity alloy, $\Delta H$ is the molar heat of fusion of the impurity, the ratio $\delta / d \approx 200 \mathrm{~s} / \mathrm{cm}$. The melting speed $v$ in the calculations was taken to be 2 and $4 \mathrm{~cm} / \mathrm{min}$. 

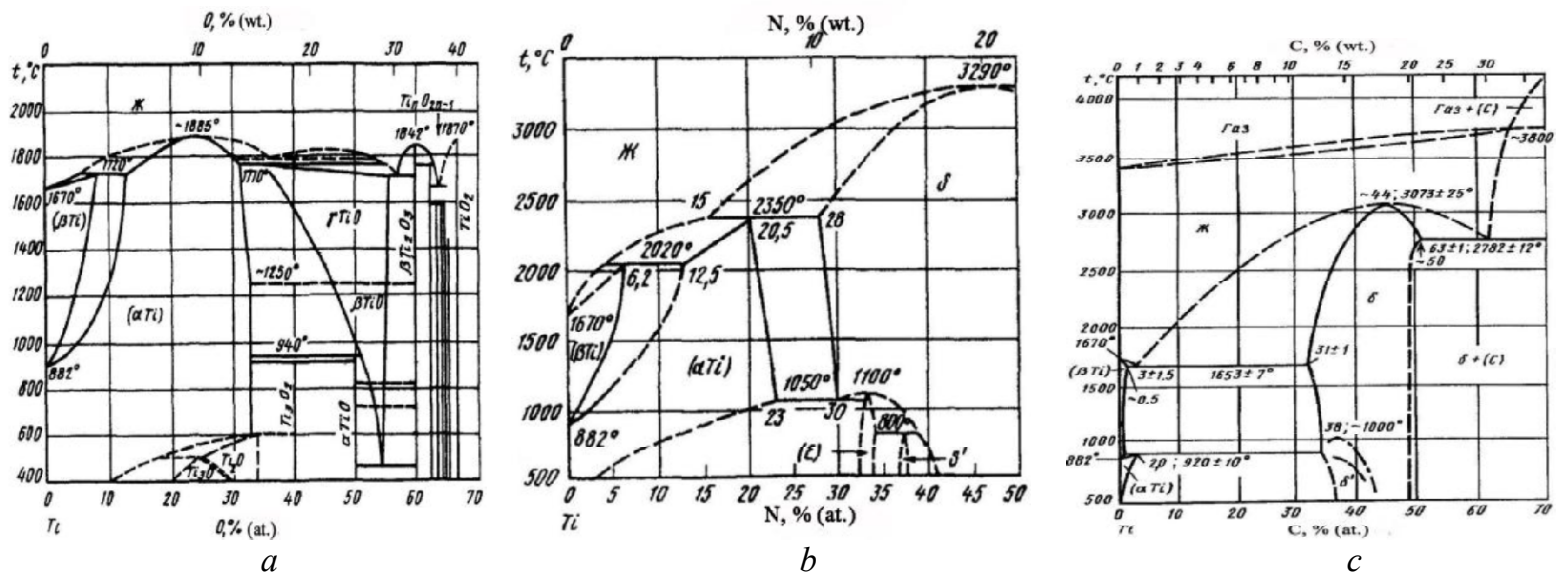

Fig. 1. Phase diagrams of Ti-O (a), Ti-N (b), and Ti-C (c) systems

Table 1 shows the calculated values of distribution coefficients for interstitial impurities. For oxygen and nitrogen, the values are $k_{0}>1$, and for carbon $k_{0}<1$. This is in good agreement with the kind of the state diagram. Also, for comparison, the values of the limiting coefficient $k_{\text {olim }}$ are given [17]. The results of calculations of $k_{0}$ and $k_{e}$ for various metallic impurities represented in the earlier work of the authors [8].

Table 1

Calculated values of $k_{0}$ and $k_{e}$ for interstitial impurities in titanium

\begin{tabular}{|c|c|c|c|c|c|}
\hline Element & $T_{G}, \mathrm{~K}$ & $\Delta H, \mathrm{~kJ} / \mathrm{mol}$ & $k_{0}$ & $k_{\text {Olim }}[12]$ & $k_{e}$ \\
\hline $\mathrm{Ti}$ & 1943 & 18.8 & 1.0 & 1.0 & 1.0 \\
\hline $\mathrm{O}$ & 1993 & 21.1 & 1.03 & 1.5 & 1.01 \\
\hline $\mathrm{C}$ & 1926 & 17 & 0.99 & 2.58 & 0.99 \\
\hline $\mathrm{N}$ & 2293 & 22 & 1.23 & 6.0 & 1.1 \\
\hline
\end{tabular}

Using the recommended values of the effective charge $\mathrm{Z}^{*}(-0.8$ for $\mathrm{O} ; 0.16$ for $\mathrm{C} ;-0.14$ for $\mathrm{N})$ and the diffusion coefficient $D$ from work [14], formulas (5)-(7) allowed to calculate the values of impurity ion mobility $U$, impurity ion displacement velocity $v^{\prime}$, effective coefficient $k_{e}^{\prime}$ for interstitial impurities. The calculation results are shown in Table 2.

In the calculations, it was taken into account that the values of $U, D, Z^{*}$ for the liquid phase of titanium may differ from the values characteristic of the $\alpha$ - and $\beta$ phases of titanium. The estimates of the values of these parameters for the liquid phase of titanium were not previously given in the works. Therefore, the calculations of the parameters for ZMEF performed in this work can be recommended only as rough estimates of the values.

Calculation results of the ZMEF process parameters for interstitial impurities in titanium

\begin{tabular}{|c|c|c|c|c|c|c|c|}
\hline \multirow{2}{*}{ Impurity } & \multirow{2}{*}{$Z^{*}[14]$} & \multirow{2}{*}{$\begin{array}{c}U, 10^{-5} \\
\mathrm{~cm}^{2} /(\mathrm{V} \cdot \mathrm{s})\end{array}$} & \multirow{2}{*}{$\begin{array}{l}D, 10^{-6}, \\
\mathrm{~cm}^{2} / \mathrm{s}\end{array}$} & \multirow{2}{*}{$\begin{array}{c}\left|v^{\prime}\right|, 10^{-6} \\
\mathrm{~cm} / \mathrm{s}\end{array}$} & \multirow{2}{*}{$\begin{array}{c}k_{e}(\text { for zone } \\
\text { melting })\end{array}$} & $k_{e}^{\prime}$ & $k_{e}^{\prime}$ \\
\hline & & & & & & $\overrightarrow{\mathrm{E}} \uparrow \downarrow \vec{v}$ & $\overrightarrow{\mathrm{E}} \uparrow \uparrow \overrightarrow{\mathrm{v}}$ \\
\hline $\mathrm{O}$ & -0.8 & 3.5 & 7.33 & 8.75 & 1.01 & 1.0 & 1.0 \\
\hline $\mathrm{C}$ & 0.16 & 1.6 & 16.8 & 4.0 & 0.99 & 0.99 & 0.65 \\
\hline $\mathrm{N}$ & -0.14 & 2.0 & 2.39 & 50.0 & 1.1 & 1.0 & 1.0 \\
\hline
\end{tabular}

As a result of the analysis of Tables 1 and 2, it can be concluded that the refining of titanium from oxygen and nitrogen takes place during preliminary heating of the sample in vacuum due to its degassing, at the melting stages during pumping out the formed gaseous molecules, due to the displacement of oxides and nitrides into the end part of the ingot. An application of electrotransport for refining from oxygen and nitrogen will be negligible.

The refining from carbon will take place as a result of preliminary heating of the sample in vacuum, at the melting stages as a result of pumping out the formed gaseous molecules, due to displacement of carbides during recrystallization. It is also possible to remove carbon when melting is carried out in an electric field plugged in along the movement of the liquid zone (melting goes from bottom to top, anode is below, cathode is above). In this case, the value of the effective charge $Z^{*}=0.16$, and the value of the effective coefficient can be equal to $k_{e}^{\prime}=0.65$ (calculated for melting at a speed of $v=4 \mathrm{~cm} / \mathrm{min}$ ).

The experimental stages of titanium refining were carried out by the method of vacuum crucibleless ZM in an electric field. A sample with a length of $250 \mathrm{~mm}$ was placed vertically. The electron beam gun had the ability to move along the ingot. The $\mathrm{ZM}$ were carried out at a controlled speed (maximum $-16 \mathrm{~mm} / \mathrm{min}$, minimum $1 \mathrm{~mm} / \mathrm{min}$ ). The length of the remelted part of the ingot was from 120 to $170 \mathrm{~mm}$, the electric field strength was $E=0.25 \mathrm{~V} / \mathrm{cm}$, the current density was $j=100 \mathrm{~A} / \mathrm{cm}^{2}$, 
and the number of zone passes was from one to three. ZMEF was carried out under the conditions of an applied direct electric field, plugged in both along and against the course of the zone. A speed of movement of the electron beam gun was 4 or $2 \mathrm{~mm} / \mathrm{min}$.

The complex technique of the refining process included the use of thermal cycling (heating and cooling

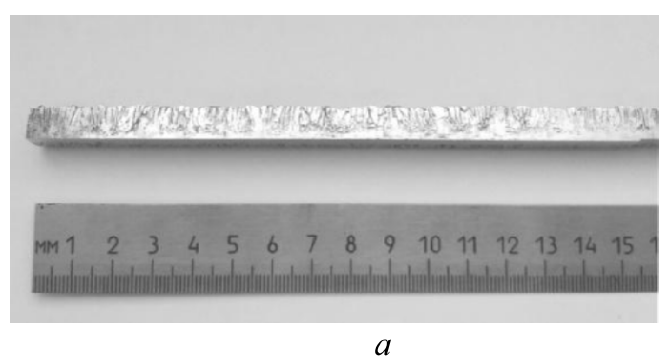

of the ingot in the temperature range of the polymorphic $\alpha-\beta$ transformation) at the final stage. This procedure contributed to the increase in grain size.

The billet of the initial iodide titanium and the sample refined by the ZMEF method are shown in Fig. 2. The ingot is obtained as a result of three ZM passes and one ZMEF pass.

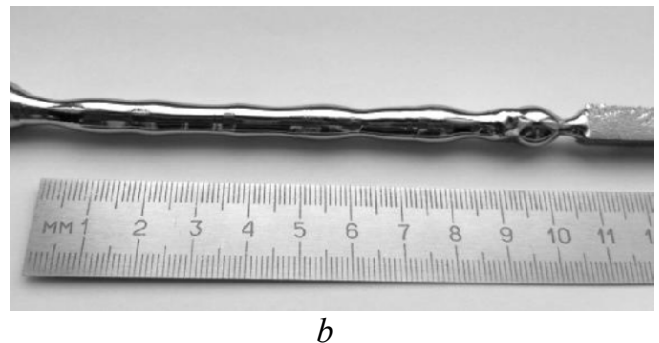

Fig. 2. View of the original billet of iodide titanium (a) and ingot after ZMEF (b)

To study the elemental composition and the content of impurities in the original iodide titanium metallography, samples in the form of tablets $6 \mathrm{~mm}$ in and ingots after refining are shown in Table 3 . The height and $8 \mathrm{~mm}$ in diameter were cut from various results are presented for samples cut from the middle of parts of the titanium rod. The results of the analysis of the ingot.

Table 3

Elemental analysis results for titanium samples

\begin{tabular}{|c|c|c|c|c|c|c|c|c|c|c|c|c|}
\hline \multirow{2}{*}{$\begin{array}{c}\text { Titanium } \\
\text { materials }\end{array}$} & \multicolumn{10}{|c|}{ Concentration, wt.\% } \\
\cline { 2 - 13 } & $\mathrm{Ti}$ & $\mathrm{Zr}$ & $\mathrm{Al}$ & $\mathrm{Fe}$ & $\mathrm{Cu}$ & $\mathrm{Cr}$ & $\mathrm{Si}$ & $\mathrm{P}$ & $\mathrm{S}$ & $\mathrm{O}$ & $\mathrm{C}$ & $\mathrm{N}$ \\
\hline iodide $\mathrm{Ti}$ & 99.88 & 0.0016 & 0.012 & 0.03 & 0.002 & $6 \cdot 10^{-3}$ & $6.2 \cdot 10^{-4}$ & $7 \cdot 10^{-5}$ & $3.5 \cdot 10^{-3}$ & 0.033 & 0.01 & $9 \cdot 10^{-3}$ \\
\hline after ZM & 99.92 & 0.0016 & 0.0073 & 0.022 & $4.5 \cdot 10^{-4}$ & $4 \cdot 10^{-3}$ & $5.2 \cdot 10^{-4}$ & $5 \cdot 10^{-5}$ & $2.9 \cdot 10^{-3}$ & 0.025 & $4.8 \cdot 10^{-3}$ & $3.5 \cdot 10^{-3}$ \\
\hline ZMEF $\overrightarrow{\mathrm{E}} \uparrow \vec{v} \vec{v}$ & 99.95 & 0.0015 & 0.0045 & 0.01 & $3 \cdot 10^{-4}$ & $3 \cdot 10^{-3}$ & $5 \cdot 10^{-4}$ & $3 \cdot 10^{-5}$ & $2 \cdot 10^{-3}$ & 0.015 & 0.004 & $4 \cdot 10^{-4}$ \\
\hline ZMEF $\overrightarrow{\mathrm{E}} \uparrow \uparrow \vec{v}$ & 99.95 & 0.0014 & 0.007 & 0.015 & $3 \cdot 10^{-4}$ & $3 \cdot 10^{-3}$ & $5 \cdot 10^{-4}$ & $3 \cdot 10^{-5}$ & $2 \cdot 10^{-3}$ & 0.017 & 0.003 & $4 \cdot 10^{-4}$ \\
\hline
\end{tabular}

The elemental analysis results showed a decrease in the concentration of a large number of metallic impurities in the melted ingots. The purification was carried out in the passage of evaporation and zone recrystallization. The use of electrotransport did not make a significant contribution to the purification from metal impurities, compared to other physical refining processes. The concentration of aluminum was reduced by 2.6 ; iron -3 ; copper -6.6 ; chromium -2 ; silicon 1.2 times.

The refining of titanium from gas-forming impurities occurred at various stages of the experiment. During preliminary heating and $\mathrm{ZM}$ at a high rate, hydrogen evaporated in the form of gaseous molecules $\left(\mathrm{H}_{2}, \mathrm{H}_{2} \mathrm{O}\right)$. The carbon was vaporized as $\mathrm{CO}$ and $\mathrm{CO}_{2}$ molecules. Nitrogen was removed by high-temperature heating and $\mathrm{ZM}$ in the form of $\mathrm{N}_{2}$ gas molecules. A decrease in the oxygen content occurred at the stages of heating and melting as a result of the formation of gaseous molecules $\mathrm{CO}, \mathrm{CO}_{2}, \mathrm{H}_{2} \mathrm{O}$.

Also, the base metal was purified due to the displacement of metal carbides and oxides into the final part of the ingot during zone recrystallization.

The use of the ZMEF method led to the migration of interstitial impurity ions to the anode or cathode under the action of an applied electric field. When melting was carried out in an electric field plugged in against the movement of the liquid zone (melting goes from bottom to top, anode is above, cathode is below), the following happened. Oxygen and nitrogen ions with negative values of the effective charge $Z^{*}$ were displaced towards the anode both in the $\alpha$-phase of the metal and in the heated section of the ingot with a hightemperature $\beta$-phase. The migration process was especially active in the liquid zone of the metal moving through the sample. Carbon ions with a positive value of $Z^{*}$ were displaced towards the cathode against the moving of the zone. But this contribution to carbon removal is less significant than the effect of zone recrystallization and evaporation processes.

When melting was carried out in an electric field plugged in along the movement of the liquid zone (melting goes from bottom to top, anode is below, cathode is above), a decrease in carbon concentration should be expected. As the carbon ions were displaced towards the cathode, coinciding with the movement of the zone. Titanium samples with a carbon content of 0.003 wt. $\%$ were obtained.

It can be concluded that electrotransport fulfills the task of effective refining only with long-time processes:

- with many hours of refining in the $\alpha$ - and $\beta$-phases of titanium, but without the use of ZM there will be no effective refining from metallic impurities;

- with multiple ZMEF processes, but in this case, the weight losses of titanium due to its evaporation begins to become noticeable.

In the samples of titanium obtained at use of the ZMEF process, the oxygen concentration was reduced 
by 2.2 (from 0.033 to 0.015 wt. $\%$ ), carbon -3.3 (from 0.01 to 0.003 wt. $\%$ ), nitrogen -22 times (from 0.009 to 0.0004 wt.\%). The purity of the samples was characterized by a value of 99.95 wt.\% by titanium content. The total amount of impurities was reduced by a factor of 2.4 (from 0.12 to $0.05 \mathrm{wt} . \%$ ).

Fig. 3 shows a photograph of the microstructure of a titanium sample after ZMEF process. Twins, as well as slip lines along prismatic planes $\{10 \overline{1} 0\}$ are visible. The grain boundaries and body were clean; the grain size was $5 \times 5 \times 5 \mathrm{~mm}$.

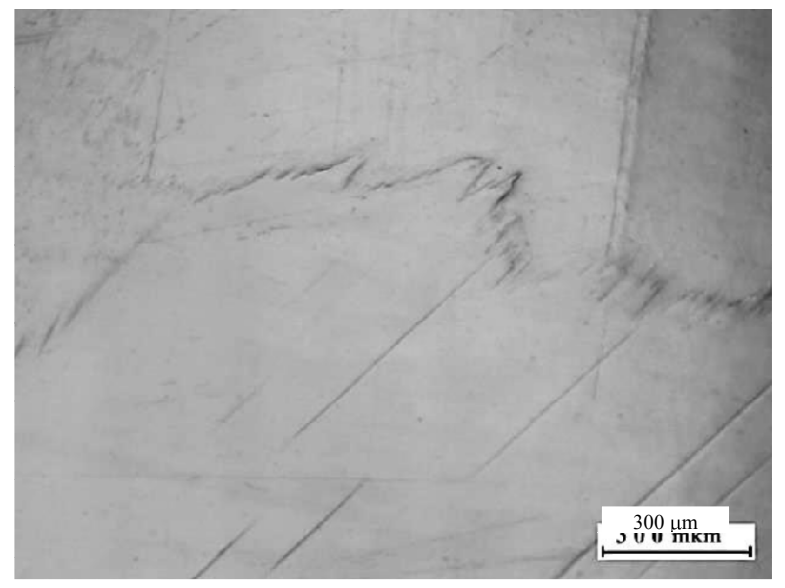

Fig. 3. Microstructure of titanium after ZMEF process

The microhardness value for the samples of the initial titanium iodide was in the range $H_{\mu}=1110 \ldots 1140 \mathrm{MPa}$. After passing through the zone recrystallization, the grains were aligned predominantly along the direction of the melting stroke (the deviation of the normal vector to the base plane from the direction of movement of the zone varied from 0 to $15^{\circ}$ ). The microhardness value after $\mathrm{ZM}$ at a high speed of 16 or $8 \mathrm{~mm} / \mathrm{min}$ was equal to $H_{\mu}=1060 \ldots 1090 \mathrm{MPa}$, after $\mathrm{ZMEF} H_{\mu}=1070 \mathrm{MPa}$.

\section{CONCLUSIONS}

The physical substantiation of the process of titanium refining from metal and interstitial impurities during ZM in a direct electric field is presented.

To obtain refined titanium samples, a method was used that included preliminary heating, vacuum crucibleless ZM, electrotransport, and thermal cycling. Purification by the ZMEF method was carried out with the simultaneous passage of several physical processes as an evaporation of gas-forming and volatile metallic impurities, zone redistribution of impurities, and migration of impurity ions under the action of an applied direct electric field.

The purity of the samples after the ZMEF method was characterized by a value of 99.95 wt.\% by titanium content. The total amount of impurities was reduced by a factor of 2.4 (from 0.12 to 0.05 wt.\%). Oxygen concentration has been reduced by 2.2 (from 0.033 to 0.015 wt.\%), carbon - by 3.3 (from 0.01 to 0.003 wt.\%), nitrogen - by 22 times (from 0.009 to 0.0004 wt.\%).

\section{REFERENCES}

1. М.Л. Коцарь, С.А. Лавриков, В.И. Никонов, А.В. Александров и др. Высокочистые титан, цирконий и гафний в ядерной энергетике // Атомная энергия. 2011, т. 111, в. 2, с. 72-77.

2. О.П. Солонина, С.Г. Глазунов. Жаропрочные титановые сплавы. М.: «Металлургия», 1976, 448 с.

3. Kang Minho, Song Jian-xun, Zhang Long, Liu Yong, et al. Preparation of high-purity titanium in $\mathrm{CaCl}_{2}-\mathrm{TiCl}_{2}$ melts // Electroplat. and Finish. 2014, v. 33, N 23, p. 1008-1011.

4. Г.А. Колобов, А.В. Карпенко, А.В. Бубинец. Рафинирующие переплавы и другие методы получения титана повышенной чистоты // Hовi матеріали $i$ технології в металургії та машинобудуванні. 2016, №2, с. 9-17.

5. M.M. Pylypenko, S.D. Lavrinenko. Pure vanadium and titanium for low activation alloys // Problems of Atomic Science and Technology. Series "Physics of Radiation Effect and Radiation Materials Science". 2016, N 4, p. 49-53.

6. В. Пфанн. Зонная плавка. М.: «Мир», 1970, $366 \mathrm{c}$.

7. Р. Лодиз, Р. Паркер. Рост монокристаллов. М.: «Мир», 1974, 540 с.

8. O.E. Kozhevnikov, M.M. Pylypenko, A.P. Shcherban, et al. The refining of titanium by crucibleless zone melting method // Problems of Atomic Science and Technology. Series "Physics of Radiation Effect and Radiation Materials Science”. 2021, N 5(135), p. 70-76.

9. А.Н. Несмеянов. Давление пара химических элементов. М.: «Изд-во АН СССР», 1961, 396 с.

10. Л.Д. Курмаева, В.А. Сазонова, Д.М. Тагирова. Структурные признаки релаксационных процессов в монокристаллах титана // ФММ. 2001, т. 92, №6, с. 57-62.

11. В.А. Михайлов, Д.Д. Богданова. Электроперенос в жидких металлах. Новосибирск: «Наука», 1978, $224 \mathrm{c}$.

12. G.P. Kovtun. Electrotransport as a way of metals deep purification // East Eur. J. Phys. 2014, v. 1, N 1, p. 37-46.

13. J. Verhoeven. Electrotransport as a Means of Purifying Metals // J. Metals. 1966, v. 18, N 1, p. 26-31.

14. O.N. Carlson, F.A. Schmidt, and R.R. Lichtenberg. Investigation of reported anomalies in the electrotransport of interstitial solutes in titanium and iron // Metallurgical Transactions. 1975, v. 6A, p. 725731.

15. П.Н. Вьюгов, О.Е. Кожевников, Т.Ю. Рудычева. Получение высокочистых образцов гафния методом бестигельной зонной плавки // Bonpocbl aтомной науки и техники. Серия "Вакуум, чистые материаль, сверхпроводники». 2009, №6(18), с. 19-24.

16. Диаграммы состояния двойных металлических систем: Справочник, т. 3, кн. 1 / Под ред. Н.П. Лякишева. М.: «Машиностроение», 2001, 872 с.

17. И. Бартел, Э. Буринг, К. Хайн, Л. Кухарж. Кристаллизачия из расплавов: Справ. изд.: Пер. с нем. М.: «Металлургия», 1987, 320 с. 


\title{
РАФИНИРОВАНИЕ ТИТАНА МЕТОДОМ ЗОННОЙ ПЕРЕКРИСТАЛЛИЗАЦИИ В ЭЛЕКТРИЧЕСКОМ ПОЛЕ
}

\author{
О.Е. Кожевников, Н.Н. Пилипенко, В.Н. Пелых, В.Д. Вирич, М.Ф. Кожевникова
}

Представлены физическое обоснование и результаты экспериментального исследования применения метода зонной перекристаллизации в электрическом поле для рафинирования титана. Изучены элементный состав, микроструктура и микротвердость образцов. Показано, что рафинирование позволило значительно снизить содержание как металлических, так и газообразующих примесей. Концентрация кислорода была снижена в 2,2 (с 0,033 до 0,015 мас.\%), углерода - в 3,3 (с 0,01 до 0,003 мас.\%), азота - в 22 раза (с 0,009 до 0,0004 мас.\%). Чистота полученных образцов характеризовалась значением 99,95 мас.\% по содержанию титана. Общее количество примесей понижено в 2,4 раза (с 0,12 до 0,05 мас.\%).

\section{РАФІНУВАННЯ ТИТАНУ МЕТОДОМ ЗОННОЇ ПЕРЕКРИСТАЛІЗАЦЇ̈ В ЕЛЕКТРИЧНОМУ ПОЛІ}

\section{О.С. Кожевніков, М.М. Пилипенко, В.М. Пелих, В.Д. Вірич, М.Ф. Кожевнікова}

Представлено фізичне обгрунтування та результати експериментального дослідження застосування методу зонної перекристалізації в електричному полі для рафінування титану. Вивчено елементний склад, мікротвердість та мікроструктура зразків. Показано, що рафінування значно зменшило вміст як металевих, так і газоутворюючих домішок. Концентрацію кисню знижено в 2,2 (з 0,033 до 0,015 мас.\%), вуглецю - в 3,3 (3 0,01 до 0,003 мас.\%), азоту - в 22 рази (з 0,009 до 0,0004 мас.\%). Чистота отриманих зразків характеризувалася значенням 99,95 мас.\% за вмістом титану. Загальну кількість домішок знижено в 2,4 рази (з 0,12 до 0,05 мас.\%). 